\title{
Probabilistic identification of streptomycetes using miniaturized physiological tests
}

\author{
PETER KÄMPFER $^{1 *}$ and REINER M. KROPPENSTEDT ${ }^{2}$ \\ ${ }^{1}$ Fachgebiet Hygiene, Technische Universität Berlin, Amrumerstr. 32, D-1000 Berlin 65, Federal Republic of Germany \\ ${ }^{2}$ Deutsche Sammlung von Mikroorganismen und Zellkulturen, Marscheroderweg 1b, D-3300 Braunschweig, \\ Federal Republic of Germany
}

(Received 26 October 1990; accepted 13 February 1991)

\begin{abstract}
A frequency matrix of positive results for phena defined in a previous phenetic classification was constructed. A total of 329 physiological characters from $\mathbf{7 8 2}$ strains was taken as the basis for this identification matrix. The minimum number of diagnostic characters for the matrix was selected using computer programs for calculation of different separation indices (CHARSEP) and selection of group diagnostic properties (DIACHAR). The resulting matrix consisted of 52 phena versus $\mathbf{5 0}$ characters. Overlap of phena was found to be relatively small (OVERMAT program). Identification scores for the most typical hypothetical organism of each phenon was satisfactory (MOSTTYP program). The matrix was evaluated theoretically and practically (MATIDEN program). For members of major clusters and subclusters, e.g. Streptomyces albidoflavus, S. halstedii, S. griseus, S. fradiae, S. rimosus and S. albus, identification scores were high. Organisms of phena containing only small numbers of strains could be identified correctly, but with lower accuracy. The identification rate of the matrix (Willcox probability $>0.90$ ) in the theoretical evaluation was $84 \cdot 39 \%$, and in the practical evaluation $78 \cdot 12 \%$.
\end{abstract}

\section{Introduction}

Current classification and identification of species within the genera Streptomyces and Streptoverticillium is based on the numerical taxonomic studies provided by Williams et al. (1983a) and Locci et al. (1981). Because of the heterogeneity of strains grouped within one species, a correct identification is polythetic and can only be obtained by probabilistic methods. Three identification matrices (Williams et al., 1983b; Langham et al., 1989a) were constructed on the basis of the results of the numerical study of Williams et al. (1983a) for members of the genus Streptomyces. For identification of members of the genus Streptoverticillium, an additional probability matrix was provided (Williams et al., 1985). Although these matrices were objectively constructed and technically sound, they depend on the numerical classifications of Locci et al. (1981) and Williams et al. (1983a), which included 111 Streptoverticillium and 394 Streptomyces strains, respectively. The probability matrix of Williams et al. $(1983 b)$ was constructed only for major phena, and

Abbreviations: OTU, operational taxonomic unit; p-NA, $p$-nitroanilide; p-NP, p-nitrophenyl. identification of members of the minor clusters required the application of an additional matrix (Langham et al., $1989 a$ ).

The more comprehensive numerical survey of Kämpfer et al. (1991) (accompanying paper), including 821 strains of the genera Streptomyces and Streptoverticillium, confirmed many of the groups found by Williams et al. (1983a), but several of the phena containing only a few strains were not detected. The taxonomic position of many strains not included in the study of Williams et al. $(1983 a)$ and currently classified within species category IV (Williams et al., 1989) was also evaluated. The results of the study by Kämpfer et al. (1991) further supported the view that strains placed in the genus Streptoverticillium, as described by Locci \& Schofield (1989), should be reclassified into the genus Streptomyces, which still seems to be overspeciated.

As identification depends heavily on classification (Sneath, 1974; Goodfellow, 1986; Hill, 1974), the results of the numerical study of Kämpfer et al. (1991) were used to construct a single probability matrix for the numerical identification of streptomycetes using miniaturized physiological tests for members of all major and minor phena. 


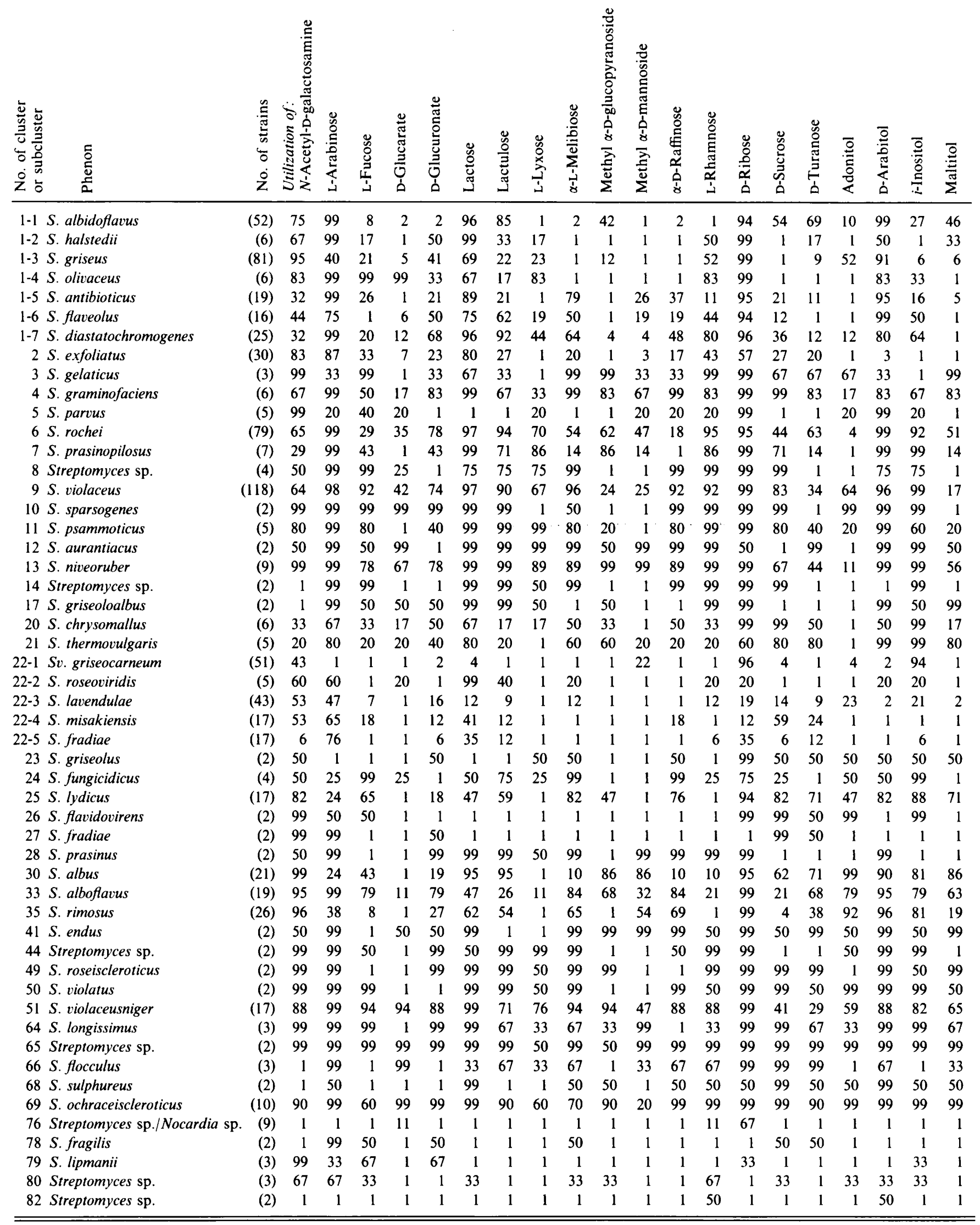




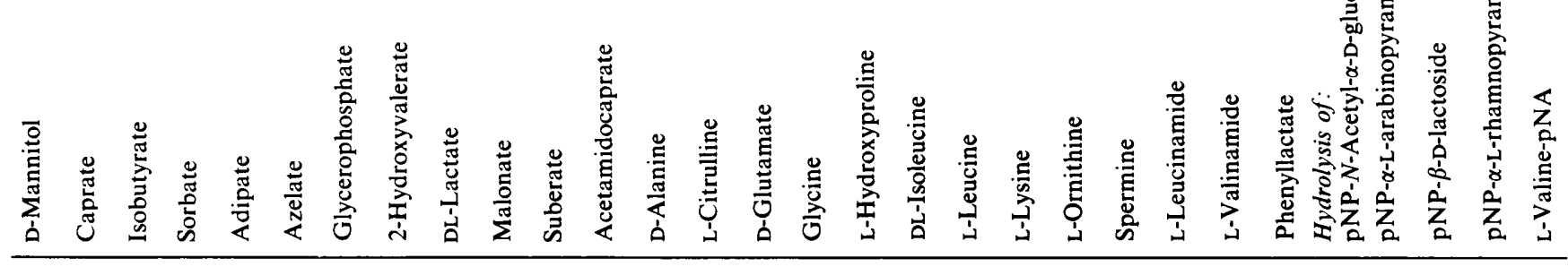

$\begin{array}{lllllllllllllllllllllllllllllll}99 & 96 & 56 & 88 & 99 & 23 & 79 & 88 & 98 & 77 & 94 & 96 & 2 & 2 & 13 & 77 & 4 & 29 & 83 & 27 & 12 & 1 & 77 & 69 & 90 & 1 & 88 & 96 & 1 & 96\end{array}$ $\begin{array}{llllllllllllllllllllllllllllllllll}50 & 83 & 17 & 17 & 50 & 17 & 1 & 17 & 50 & 1 & 17 & 17 & 83 & 1 & 99 & 50 & 17 & 1 & 33 & 33 & 1 & 1 & 33 & 50 & 17 & 1 & 99 & 17 & 1 & 1\end{array}$ $\begin{array}{lllllllllllllllllllllllllllllll}99 & 78 & 85 & 62 & 11 & 67 & 1 & 23 & 83 & 4 & 57 & 25 & 10 & 7 & 4 & 67 & 75 & 43 & 44 & 33 & 19 & 9 & 36 & 69 & 9 & 1 & 19 & 19 & 51 & 51\end{array}$ $\begin{array}{lllllllllllllllllllllllllllllllll}99 & 83 & 99 & 1 & 99 & 33 & 33 & 33 & 99 & 83 & 83 & 1 & 50 & 1 & 17 & 50 & 1 & 67 & 83 & 83 & 1 & 1 & 83 & 33 & 50 & 1 & 99 & 83 & 83 & 1\end{array}$ $\begin{array}{lllllllllllllllllllllllllllllll}95 & 74 & 16 & 32 & 5 & 89 & 5 & 11 & 5 & 1 & 37 & 5 & 21 & 21 & 16 & 32 & 16 & 21 & 5 & 26 & 63 & 11 & 5 & 42 & 26 & 1 & 58 & 58 & 16 & 68\end{array}$ $\begin{array}{lllllllllllllllllllllllllllllllllll}99 & 88 & 94 & 99 & 12 & 99 & 19 & 50 & 31 & 1 & 62 & 25 & 19 & 69 & 50 & 62 & 56 & 38 & 38 & 75 & 94 & 6 & 25 & 38 & 62 & 6 & 25 & 50 & 12 & 69\end{array}$ $\begin{array}{llllllllllllllllllllllllllllllllll}76 & 52 & 80 & 60 & 4 & 32 & 12 & 8 & 8 & 8 & 48 & 12 & 40 & 64 & 68 & 72 & 40 & 68 & 36 & 36 & 92 & 4 & 56 & 88 & 32 & 4 & 88 & 80 & 24 & 44\end{array}$ $\begin{array}{llllllllllllllllllllllllllllll}3 & 87 & 83 & 73 & 10 & 87 & 17 & 73 & 43 & 1 & 83 & 20 & 60 & 7 & 47 & 73 & 93 & 67 & 90 & 87 & 40 & 87 & 77 & 57 & 43 & 3 & 67 & 70 & 13 & 77\end{array}$ $\begin{array}{llllllllllllllllllllllllllllllll}33 & 67 & 67 & 67 & 1 & 67 & 99 & 1 & 99 & 33 & 33 & 1 & 99 & 1 & 67 & 1 & 99 & 33 & 67 & 33 & 33 & 33 & 33 & 1 & 33 & 99 & 33 & 67 & 67 & 33\end{array}$ $\begin{array}{llllllllllllllllllllllllllllllll}83 & 67 & 67 & 17 & 67 & 33 & 17 & 1 & 83 & 33 & 67 & 33 & 33 & 50 & 17 & 50 & 50 & 99 & 67 & 99 & 99 & 17 & 99 & 99 & 17 & 67 & 67 & 83 & 1 & 83\end{array}$ $\begin{array}{lllllllllllllllllllllllllllllllllll}99 & 40 & 20 & 60 & 1 & 60 & 20 & 20 & 20 & 20 & 60 & 20 & 40 & 1 & 1 & 40 & 40 & 20 & 60 & 20 & 1 & 60 & 1 & 60 & 40 & 99 & 80 & 80 & 40 & 99\end{array}$ $\begin{array}{lllllllllllllllllllllllllllllllll}99 & 86 & 72 & 78 & 23 & 68 & 25 & 54 & 61 & 56 & 84 & 72 & 20 & 75 & 68 & 80 & 38 & 53 & 73 & 63 & 85 & 1 & 56 & 70 & 68 & 5 & 97 & 95 & 63 & 73\end{array}$ $\begin{array}{lllllllllllllllllllllllllllllll}99 & 86 & 14 & 99 & 1 & 57 & 1 & 57 & 57 & 14 & 86 & 86 & 99 & 71 & 14 & 86 & 1 & 43 & 99 & 14 & 57 & 1 & 86 & 71 & 99 & 1 & 71 & 99 & 99 & 99\end{array}$ $\begin{array}{llllllllllllllllllllllllllllllllll}75 & 1 & 1 & 1 & 1 & 1 & 1 & 25 & 50 & 75 & 75 & 75 & 50 & 75 & 99 & 25 & 75 & 50 & 75 & 1 & 99 & 1 & 99 & 25 & 50 & 50 & 99 & 75 & 99 & 1\end{array}$ $\begin{array}{llllllllllllllllllllllllllllllll}97 & 72 & 85 & 72 & 19 & 49 & 42 & 31 & 32 & 35 & 64 & 73 & 36 & 69 & 70 & 77 & 74 & 44 & 53 & 70 & 90 & 5 & 50 & 71 & 51 & 6 & 93 & 97 & 66 & 33\end{array}$ $\begin{array}{lllllllllllllllllllllllllllllll}99 & 99 & 50 & 1 & 1 & 1 & 50 & 1 & 99 & 50 & 50 & 99 & 1 & 99 & 99 & 50 & 99 & 99 & 50 & 50 & 50 & 1 & 50 & 1 & 1 & 99 & 99 & 99 & 99 & 50\end{array}$ $\begin{array}{llllllllllllllllllllllllllllllll}60 & 80 & 99 & 60 & 1 & 20 & 20 & 60 & 99 & 1 & 40 & 40 & 1 & 20 & 99 & 80 & 99 & 60 & 99 & 60 & 99 & 1 & 60 & 99 & 80 & 1 & 99 & 40 & 99 & 20\end{array}$ $\begin{array}{llllllllllllllllllllllllllllllllll}99 & 1 & 50 & 50 & 1 & 1 & 50 & 50 & 50 & 99 & 99 & 99 & 99 & 99 & 99 & 1 & 50 & 99 & 99 & 1 & 99 & 1 & 99 & 50 & 99 & 1 & 99 & 99 & 99 & 1\end{array}$ $\begin{array}{llllllllllllllllllllllllllllll}99 & 33 & 78 & 44 & 44 & 67 & 78 & 44 & 67 & 89 & 67 & 89 & 89 & 89 & 67 & 99 & 89 & 89 & 89 & 67 & 99 & 1 & 78 & 89 & 89 & 33 & 89 & 99 & 99 & 22\end{array}$ $\begin{array}{llllllllllllllllllllllllllllllllllllll}1 & 50 & 99 & 50 & 1 & 50 & 50 & 1 & 1 & 1 & 1 & 1 & 50 & 1 & 50 & 50 & 1 & 1 & 1 & 1 & 1 & 1 & 99 & 1 & 50 & 1 & 99 & 99 & 99 & 50\end{array}$ $\begin{array}{lllllllllllllllllllllllllllllllll}99 & 50 & 1 & 1 & 1 & 1 & 99 & 50 & 50 & 50 & 99 & 50 & 1 & 99 & 1 & 1 & 50 & 1 & 1 & 99 & 99 & 1 & 1 & 1 & 50 & 1 & 99 & 99 & 50 & 1\end{array}$ $\begin{array}{llllllllllllllllllllllllllllllllll}50 & 33 & 33 & 17 & 17 & 17 & 83 & 1 & 99 & 17 & 50 & 83 & 83 & 83 & 17 & 50 & 83 & 1 & 99 & 83 & 67 & 17 & 67 & 83 & 50 & 1 & 17 & 1 & 17 & 99\end{array}$ $\begin{array}{lllllllllllllllllllllllllllllll}99 & 99 & 40 & 60 & 1 & 40 & 1 & 99 & 80 & 1 & 40 & 99 & 99 & 80 & 40 & 80 & 40 & 60 & 60 & 20 & 99 & 20 & 80 & 99 & 80 & 40 & 80 & 40 & 1 & 60\end{array}$ $\begin{array}{lllllllllllllllllllllllllllllll}12 & 25 & 55 & 16 & 6 & 18 & 84 & 20 & 18 & 6 & 27 & 10 & 14 & 39 & 10 & 76 & 78 & 71 & 90 & 98 & 84 & 49 & 80 & 86 & 57 & 78 & 10 & 22 & 12 & 96\end{array}$ $\begin{array}{llllllllllllllllllllllllllllllllll}20 & 80 & 80 & 60 & 1 & 40 & 1 & 1 & 1 & 1 & 1 & 20 & 1 & 1 & 60 & 60 & 60 & 1 & 1 & 80 & 20 & 60 & 20 & 20 & 1 & 1 & 99 & 80 & 1 & 99\end{array}$ $\begin{array}{llllllllllllllllllllllllllllllll}2 & 51 & 19 & 19 & 14 & 40 & 12 & 2 & 7 & 14 & 65 & 21 & 77 & 23 & 23 & 91 & 98 & 49 & 84 & 98 & 49 & 74 & 56 & 56 & 21 & 14 & 14 & 12 & 1 & 42\end{array}$ $\begin{array}{llllllllllllllllllllllllllllllll}1 & 59 & 59 & 12 & 1 & 1 & 1 & 65 & 6 & 1 & 6 & 1 & 6 & 1 & 18 & 53 & 82 & 47 & 88 & 65 & 6 & 76 & 53 & 59 & 53 & 12 & 35 & 12 & 1 & 53\end{array}$ $\begin{array}{lllllllllllllllllllllllllllllllllll}1 & 88 & 76 & 6 & 18 & 29 & 1 & 24 & 6 & 1 & 41 & 6 & 53 & 47 & 1 & 88 & 71 & 53 & 41 & 82 & 71 & 12 & 35 & 35 & 12 & 1 & 94 & 53 & 1 & 99\end{array}$ $\begin{array}{llllllllllllllllllllllllllllllllll}99 & 50 & 50 & 1 & 1 & 1 & 1 & 1 & 99 & 1 & 1 & 1 & 50 & 50 & 50 & 99 & 1 & 99 & 50 & 99 & 50 & 99 & 1 & 99 & 99 & 1 & 50 & 1 & 1 & 99\end{array}$ $\begin{array}{lllllllllllllllllllllllllllllllllll}75 & 1 & 1 & 1 & 1 & 25 & 25 & 1 & 75 & 1 & 1 & 25 & 99 & 25 & 1 & 99 & 50 & 1 & 1 & 50 & 75 & 1 & 1 & 25 & 1 & 1 & 1 & 1 & 1 & 1\end{array}$ $\begin{array}{lllllllllllllllllllllllllllllll}82 & 88 & 12 & 41 & 6 & 24 & 59 & 1 & 59 & 6 & 41 & 41 & 88 & 71 & 53 & 82 & 94 & 35 & 6 & 82 & 94 & 29 & 12 & 71 & 53 & 59 & 18 & 24 & 1 & 99\end{array}$ $\begin{array}{lllllllllllllllllllllllllllllllll}1 & 99 & 99 & 1 & 50 & 99 & 50 & 1 & 99 & 1 & 1 & 99 & 99 & 99 & 1 & 50 & 50 & 50 & 99 & 1 & 99 & 1 & 1 & 50 & 1 & 50 & 50 & 50 & 1 & 99\end{array}$ $\begin{array}{llllllllllllllllllllllllllllllll}1 & 50 & 99 & 1 & 50 & 99 & 1 & 99 & 99 & 50 & 99 & 1 & 1 & 50 & 50 & 1 & 50 & 99 & 50 & 50 & 1 & 50 & 99 & 50 & 50 & 1 & 50 & 50 & 1 & 1\end{array}$ $\begin{array}{llllllllllllllllllllllllllllllll}99 & 1 & 1 & 1 & 1 & 99 & 1 & 1 & 1 & 1 & 50 & 50 & 1 & 50 & 99 & 99 & 1 & 99 & 50 & 99 & 50 & 1 & 99 & 99 & 99 & 1 & 50 & 99 & 50 & 99\end{array}$ $\begin{array}{lllllllllllllllllllllllllllllll}99 & 81 & 81 & 48 & 5 & 5 & 86 & 86 & 57 & 5 & 19 & 62 & 48 & 33 & 90 & 81 & 81 & 76 & 71 & 76 & 43 & 5 & 67 & 76 & 95 & 99 & 99 & 99 & 1 & 99\end{array}$ $\begin{array}{lllllllllllllllllllllllllllllll}95 & 37 & 84 & 53 & 21 & 84 & 95 & 84 & 63 & 47 & 95 & 74 & 74 & 47 & 74 & 95 & 95 & 84 & 95 & 89 & 89 & 21 & 84 & 95 & 99 & 42 & 37 & 26 & 11 & 89\end{array}$ $\begin{array}{llllllllllllllllllllllllllllll}99 & 85 & 92 & 42 & 15 & 58 & 99 & 54 & 88 & 35 & 69 & 69 & 81 & 81 & 54 & 92 & 1 & 85 & 85 & 92 & 88 & 96 & 69 & 77 & 92 & 8 & 19 & 46 & 4 & 88\end{array}$ $\begin{array}{lllllllllllllllllllllllllllllll}99 & 1 & 50 & 1 & 1 & 1 & 99 & 99 & 50 & 1 & 1 & 50 & 50 & 50 & 99 & 99 & 50 & 1 & 50 & 99 & 99 & 1 & 1 & 1 & 99 & 99 & 99 & 99 & 1 & 99\end{array}$ $\begin{array}{llllllllllllllllllllllllllllllll}99 & 1 & 99 & 1 & 99 & 99 & 99 & 99 & 99 & 99 & 99 & 1 & 99 & 99 & 50 & 99 & 99 & 99 & 50 & 99 & 99 & 1 & 50 & 99 & 99 & 50 & 50 & 99 & 50 & 50\end{array}$ $\begin{array}{lllllllllllllllllllllllllllllll}99 & 1 & 1 & 50 & 1 & 50 & 99 & 50 & 50 & 99 & 50 & 50 & 99 & 99 & 1 & 1 & 1 & 1 & 50 & 50 & 50 & 1 & 99 & 1 & 99 & 1 & 99 & 99 & 1 & 1\end{array}$ $\begin{array}{lllllllllllllllllllllllllllllllll}99 & 50 & 99 & 1 & 99 & 99 & 99 & 50 & 99 & 1 & 99 & 99 & 99 & 99 & 1 & 99 & 99 & 1 & 50 & 99 & 99 & 1 & 1 & 1 & 50 & 1 & 99 & 99 & 50 & 50\end{array}$ $\begin{array}{lllllllllllllllllllllllllllllllll}99 & 6 & 41 & 1 & 29 & 6 & 71 & 47 & 76 & 35 & 29 & 59 & 94 & 47 & 47 & 24 & 76 & 65 & 65 & 59 & 88 & 1 & 47 & 35 & 41 & 82 & 59 & 76 & 35 & 6\end{array}$ $\begin{array}{lllllllllllllllllllllllllllllll}99 & 1 & 99 & 67 & 33 & 99 & 33 & 67 & 99 & 99 & 99 & 99 & 99 & 99 & 99 & 99 & 99 & 99 & 99 & 99 & 99 & 33 & 99 & 67 & 99 & 1 & 67 & 67 & 33 & 99\end{array}$ $\begin{array}{lllllllllllllllllllllllllllllll}99 & 1 & 50 & 1 & 1 & 1 & 1 & 1 & 99 & 50 & 50 & 50 & 99 & 99 & 99 & 1 & 99 & 99 & 50 & 99 & 99 & 1 & 50 & 99 & 99 & 99 & 99 & 99 & 99 & 1\end{array}$ $\begin{array}{lllllllllllllllllllllllllllllll}99 & 99 & 67 & 33 & 33 & 99 & 1 & 67 & 99 & 99 & 99 & 67 & 67 & 33 & 33 & 33 & 1 & 67 & 67 & 1 & 1 & 1 & 33 & 99 & 67 & 1 & 33 & 1 & 33 & 67\end{array}$ $\begin{array}{lllllllllllllllllllllllllllllllllll}99 & 99 & 99 & 99 & 1 & 50 & 50 & 99 & 99 & 50 & 50 & 99 & 50 & 99 & 1 & 1 & 1 & 99 & 99 & 1 & 99 & 1 & 99 & 50 & 99 & 99 & 50 & 50 & 1 & 99\end{array}$ $\begin{array}{llllllllllllllllllllllllllllllll}99 & 80 & 90 & 70 & 99 & 90 & 99 & 99 & 99 & 80 & 80 & 99 & 99 & 99 & 50 & 90 & 90 & 99 & 99 & 99 & 99 & 1 & 99 & 99 & 70 & 80 & 80 & 80 & 70 & 99\end{array}$ $\begin{array}{lllllllllllllllllllllllllllllllllll}1 & 99 & 89 & 99 & 1 & 89 & 1 & 89 & 56 & 1 & 78 & 67 & 1 & 1 & 1 & 1 & 1 & 56 & 56 & 1 & 1 & 1 & 56 & 22 & 1 & 1 & 11 & 1 & 11 & 56\end{array}$ $\begin{array}{llllllllllllllllllllllllllllll}1 & 1 & 1 & 50 & 1 & 1 & 1 & 1 & 1 & 1 & 1 & 1 & 1 & 1 & 1 & 1 & 1 & 1 & 1 & 1 & 1 & 1 & 1 & 1 & 50 & 1 & 99 & 50 & 1 & 1\end{array}$ $\begin{array}{llllllllllllllllllllllllllllllll}1 & 1 & 67 & 1 & 1 & 1 & 1 & 1 & 1 & 33 & 33 & 1 & 1 & 1 & 33 & 33 & 33 & 1 & 1 & 1 & 1 & 33 & 33 & 67 & 67 & 33 & 1 & 1 & 1 & 67\end{array}$ $\begin{array}{llllllllllllllllllllllllllllllll}33 & 33 & 1 & 1 & 33 & 67 & 1 & 1 & 1 & 1 & 67 & 33 & 1 & 1 & 1 & 1 & 33 & 1 & 33 & 1 & 1 & 1 & 1 & 1 & 1 & 1 & 33 & 67 & 1 & 1\end{array}$ $\begin{array}{lllllllllllllllllllllllllllllllll}50 & 1 & 1 & 1 & 1 & 1 & 1 & 50 & 1 & 1 & 50 & 1 & 50 & 1 & 1 & 50 & 1 & 1 & 1 & 1 & 1 & 1 & 1 & 1 & 1 & 1 & 1 & 1 & 1 & 1\end{array}$ 
Table 2. A diagnostic table for Streptomyces species defined

Single-member cluster
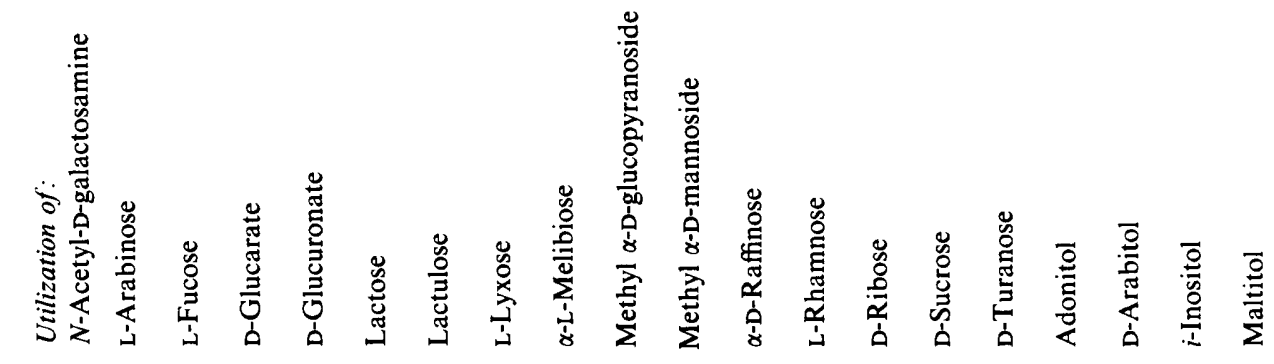

Sv. luteoreticuli ISP 5509

$S$. massasporeus ISP 5035

S. lanatus ISP 5090

$S$. griseoruber ISP 5281

S. cyaneogriseus ISP 5534

S. loidensis DSM 40825

S. albus ISP $5313^{\mathrm{T}}$

S. fulvissimus ISP $5593^{\mathrm{T}}$

S. varsoviensis ISP $5346^{\mathrm{T}}$

S. luteofluorescens ISP 5398

S. caelicus DSM 40835

S. spheroides ISP 5292

S. olivaceus ISP 5072

$S$. niveus ISP 5088

S. scabies DSM 40961

S. pallidus ISP 5531

$S$. anulatus ISP $5361^{\mathrm{T}}$

S. parvulus DSM 40722

S. bluensis ISP 5564

S. hygroscopicus DSM 40822

S. caeruleus ISP $5103^{\mathrm{T}}$

Streptomyces sp. DSM 40966

S. malachiticus ISP 5167

S. bellus ISP 5185

S. xantholiticus ISP 5244

S. albosporeus DSM $40975^{\mathrm{T}}$

Nocardia sp. DSM 40297

S. fradiae DSM 40943

S. poonensis ISP 5596

Streptomyces sp. DSM 40857

S. olivaceus DSM 40756

S. erythrogriseus ISP 5116

$S$. bambergiensis ISP $5590^{\mathrm{T}}$

S. ipomoeae ISP 5383

S. exfoliatus DSM 40735

S. aureofaciens DSM 40643

S. xanthophaeus ISP 5134

S. hygroscopicus ISP 5578

S. coelicolor DSM 40674

A. autotrophica ISP 5011

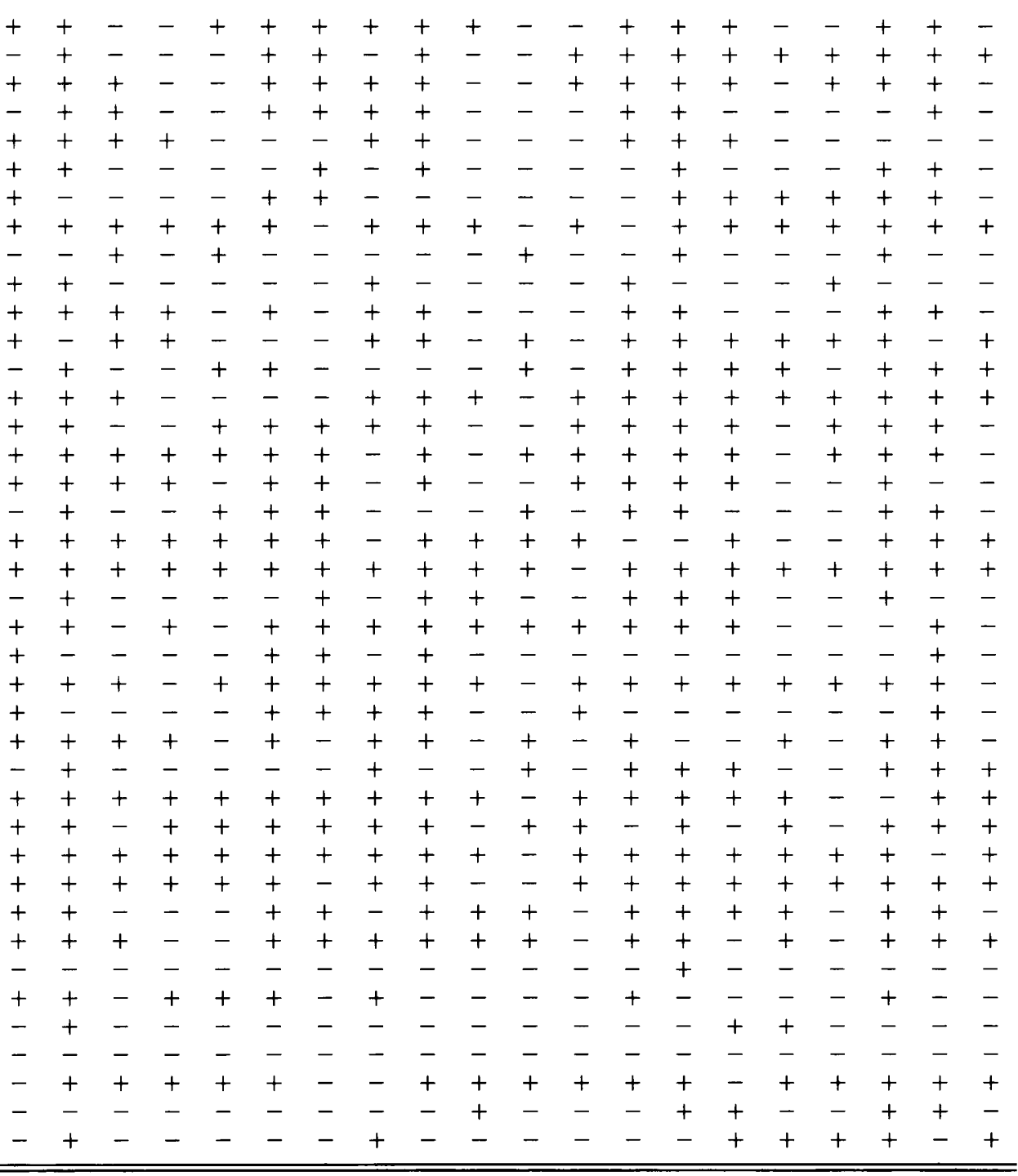




\begin{tabular}{|c|c|c|c|c|c|c|c|c|c|c|c|c|c|c|c|c|c|c|c|c|c|c|c|c|c|c|c|c|c|}
\hline 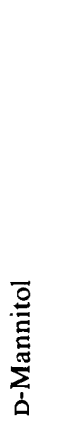 & 总 & 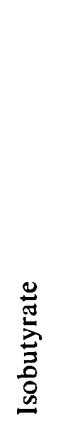 & 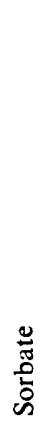 & 营 & $\frac{\stackrel{0}{\frac{\pi}{N}}}{<}$ & 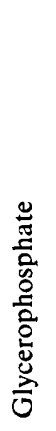 & 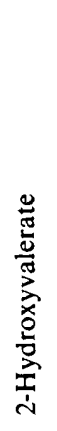 & 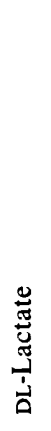 & 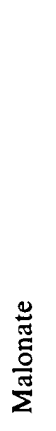 & 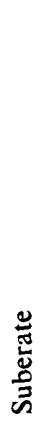 & 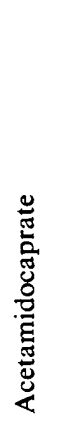 & 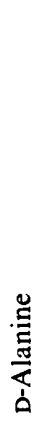 & 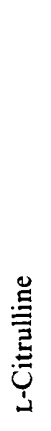 & 胥 & $\frac{\stackrel{\Xi}{0}}{0}$ & 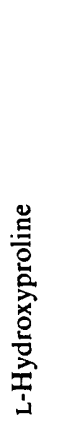 & 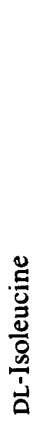 & 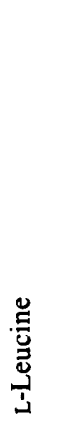 & 莣 & 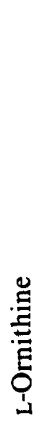 & 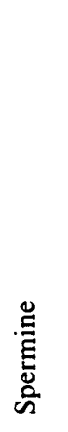 & 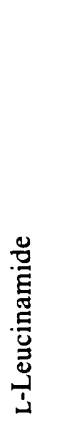 & 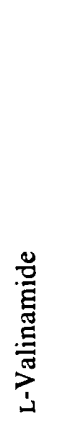 & 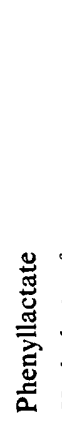 & 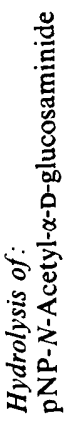 & 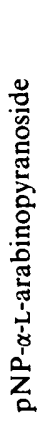 & 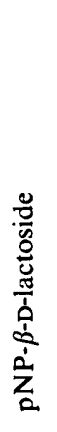 & 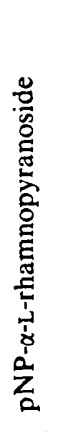 & 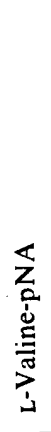 \\
\hline+ & - & + & + & - & + & - & - & + & - & - & - & + & + & - & + & + & + & - & + & + & - & - & + & + & - & + & + & - & + \\
\hline+ & + & - & + & - & - & + & - & + & - & + & - & + & + & + & + & + & + & - & + & + & - & + & + & - & - & + & + & - & + \\
\hline+ & + & + & + & - & + & + & - & + & - & + & + & + & + & - & + & + & - & - & + & + & - & - & + & + & - & + & + & + & - \\
\hline- & + & + & - & - & + & - & + & - & + & + & + & - & + & + & + & + & + & - & + & + & - & - & + & + & - & + & + & + & - \\
\hline- & + & - & - & + & + & - & + & + & - & + & - & + & + & + & - & + & + & + & + & + & - & + & + & + & - & + & - & + & - \\
\hline+ & - & - & - & - & + & + & + & + & - & + & + & - & - & + & + & + & - & + & + & + & - & - & + & + & + & + & + & - & + \\
\hline+ & + & + & - & - & - & + & + & + & - & - & - & + & + & + & + & + & - & - & + & + & - & + & - & - & + & + & + & - & + \\
\hline+ & + & + & - & - & + & + & + & + & + & + & + & + & - & + & + & + & + & + & + & + & - & + & + & + & - & - & - & - & + \\
\hline+ & + & + & + & - & - & + & - & - & - & - & - & - & - & - & + & - & - & + & + & + & - & - & + & - & + & - & - & + & + \\
\hline+ & + & + & - & - & + & - & + & + & - & + & + & + & + & - & - & + & + & + & - & + & - & + & - & + & + & - & - & + & + \\
\hline+ & - & + & - & - & + & - & - & + & - & + & - & - & + & + & + & - & - & + & + & + & - & + & - & - & - & - & - & - & - \\
\hline+ & - & - & - & - & - & - & + & + & - & - & - & + & - & - & - & + & - & + & + & + & - & + & + & - & + & - & - & + & - \\
\hline+ & - & + & - & - & - & + & - & + & - & + & + & + & - & - & + & + & - & - & - & - & - & - & - & + & - & + & - & - & + \\
\hline+ & - & - & - & - & - & + & - & + & + & - & + & - & - & + & + & + & - & - & + & - & - & - & - & + & + & + & + & + & + \\
\hline+ & - & + & - & + & + & + & - & + & + & + & - & + & + & + & + & + & + & + & - & + & - & + & - & - & - & + & + & + & + \\
\hline+ & + & + & + & - & + & + & + & - & + & + & + & - & + & + & + & + & + & + & - & + & - & + & + & + & - & + & + & - & + \\
\hline+ & + & + & - & - & + & - & + & + & + & + & - & - & - & - & + & + & - & + & - & - & + & + & + & + & - & - & + & + & + \\
\hline+ & - & + & + & - & - & + & - & + & - & - & - & + & + & + & - & - & + & - & - & + & - & - & - & - & + & + & + & + & - \\
\hline+ & - & - & + & - & - & + & - & + & + & - & + & + & - & - & + & - & - & - & - & + & - & + & + & + & - & + & + & + & + \\
\hline+ & - & + & - & - & - & + & + & + & - & - & $t$ & - & - & - & - & - & - & + & + & + & - & 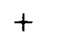 & + & + & + & + & + & - & + \\
\hline+ & - & + & - & + & - & - & - & + & - & - & - & - & - & - & - & - & + & - & + & . & - & - & + & - & - & + & - & - & + \\
\hline- & - & - & - & - & - & - & + & + & - & - & - & + & - & - & - & - & - & - & - & - & - & - & - & + & + & + & + & + & + \\
\hline- & - & - & - & - & + & - & - & - & - & - & + & + & + & - & + & + & + & + & + & + & - & - & - & - & + & + & + & + & - \\
\hline+ & + & + & + & + & - & - & + & + & - & + & + & + & + & - & + & + & - & + & + & + & - & - & + & + & + & + & + & + & - \\
\hline- & - & - & - & + & + & - & + & + & - & + & + & + & + & + & - & + & + & + & + & + & - & + & + & + & - & - & - & - & + \\
\hline+ & - & + & - & + & - & - & + & + & + & + & + & + & - & - & + & + & + & + & + & + & - & + & + & + & - & + & - & - & - \\
\hline+ & + & + & + & + & + & + & + & + & - & + & + & + & + & - & + & + & + & + & + & + & - & 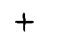 & + & + & + & + & - & - & - \\
\hline+ & - & + & - & + & + & - & - & + & + & + & + & + & + & - & - & - & + & + & + & + & + & + & + & + & - & + & + & - & + \\
\hline+ & + & + & - & + & + & + & + & + & + & + & + & + & + & - & + & - & + & + & - & + & - & + & + & + & + & + & + & + & - \\
\hline+ & + & + & + & + & - & - & + & + & + & + & + & + & - & + & + & - & - & + & - & - & - & + & + & + & - & + & + & - & + \\
\hline+ & + & + & + & - & + & + & + & + & - & + & + & - & + & + & - & + & + & + & + & - & + & + & - & - & + & - & - & + & + \\
\hline+ & + & + & + & + & + & - & - & + & + & + & + & + & + & + & + & - & + & + & + & + & - & - & - & + & - & + & + & - & + \\
\hline+ & - & + & - & + & + & + & + & + & + & + & + & + & + & - & + & - & + & + & + & + & - & - & + & + & - & + & + & + & + \\
\hline- & + & + & + & - & - & - & + & + & - & - & - & - & - & - & - & - & - & - & - & - & - & - & - & - & - & - & - & - & + \\
\hline+ & - & + & - & - & - & - & - & - & - & + & - & - & + & - & - & - & - & - & - & - & - & - & - & - & - & - & + & - & - \\
\hline- & - & - & - & - & - & - & - & - & - & - & - & - & - & - & - & + & + & - & + & - & - & + & - & - & - & - & - & - & + \\
\hline- & - & - & - & - & - & - & - & + & + & + & - & + & - & - & + & + & - & - & - & - & - & - & - & - & + & - & - & - & - \\
\hline+ & - & - & - & - & - & + & - & - & - & - & + & + & + & + & + & + & + & + & + & + & + & - & - & - & + & - & + & - & + \\
\hline- & - & - & - & - & - & + & + & + & + & - & - & - & - & - & + & - & - & + & - & + & - & + & - & + & - & - & - & - & - \\
\hline+ & + & + & - & + & + & - & + & + & - & + & + & + & - & - & - & - & + & + & - & + & - & + & + & - & - & + & - & - & + \\
\hline
\end{tabular}




\section{Methods}

Clusters. Details on the origins of strains and the composition of clusters were given by Kämpfer et al. (1991). The single-member clusters obtained in that study were not included in the matrix; the test results for these are given as a diagnostic table.

Some phena containing related strains and showing much overlap were regarded as one group. The minor clusters 51, 53, 54, 55 and 57, containing strains of Streptomyces violaceusniger and $S$. hygroscopicus, were joined. Cluster 30 ( $S$. albus) was grouped with clusters 31 ( $S$. cacaoi) and 32 (S.albus), with which it showed much overlap. Similarly, clusters 35 and 36 , both containing strains of $S$. rimosus, were grouped together. Names of the clusters were adopted from the study of Kämpfer et al. (1991).

Selection of the most diagnostic characters. Procedures for objective character selection have been described in detail by Sneath $(1979 b$; $1980 a, b)$. These procedures have been successfully applied to streptomycetes in the studies of Williams et al. $(1983 b ; 1985)$ and Langham et al. (1989a).

The minimum number of characters was selected trom the 329 characters used by Kämpfer et al. (1991). From the several separation indices provided by the CHARSEP program (Sneath, 1979 $b$ ), the VSP index (variance of separation potential) was chosen to find the best differentiating characters. Fifty characters were chosen for the matrix. The selected characters were assessed using the MOSTTYP program (Sneath, 1980b), which provides the identification scores of the Willcox probability (Willcox et al., 1973), the taxonomic distance and the standard error of the taxonomic distance for the hypothetical median organism of each cluster. The DIACHAR program (Sneath, 1980a) was used to assess the chosen characters.

Determination of characteristics in the matrix. Each strain was tested for 50 characters (Table 1) including carbon source utilization tests and qualitative enzyme tests using chromogenic substrates. Tests were performed in standard microtitration plates (Greiner, Nürtingen, FRG). All tests were read both visually and photometrically.

All strains were cultivated on glucose/yeast extract/malt extract agar (GYM) containing the following constituents $\left(\mathrm{g}^{-1}\right)$ : yeast extract, 4 ; malt extract, $10 ; \mathrm{D}$-glucose, $4 ; \mathrm{CaCO}_{3}, 2 ;$ agar, 15 . They were incubated aerobically at $28^{\circ} \mathrm{C}$.

(i) Carbon source utilization. Growth on different carbon sources was tested in a mineral medium containing the following constituents ( $\mathrm{g}$ $\left.1^{-1}\right): \mathrm{K}_{2} \mathrm{HPO}_{4}$. $1 \cdot 74 ; \mathrm{KH}_{2} \mathrm{PO}_{4}, 1 \cdot 36 ;\left(\mathrm{NH}_{4}\right)_{2} \mathrm{SO}_{4}, 5 \cdot 0 ; \mathrm{MgSO}_{4} .7 \mathrm{H}_{2} \mathrm{O}$, $0.5 ; \mathrm{CaCl}_{2} .2 \mathrm{H}_{2} \mathrm{O}, 0.1 ; \mathrm{NaCl}, 9.0$; yeast extract (Oxoid), 0.02 ; biolactysate (bio-Merieux), 0.02 ; vitamin solution, $5 \mathrm{ml}$ [containing (mg $1^{-1}$ ): calcium pantothenate, $0 \cdot 1$; nicotinic acid, $0 \cdot 1$; biotin, $0 \cdot 005$; cyanocobalamin, 0.005 ; folic acid, 0.1 ; pyridoxine, $0 \cdot 1 ; p$-aminobenzoic acid, $0 \cdot 1$; thiamin pyrophosphate, $0 \cdot 1$; inositol, $0 \cdot 1$; thiamin, $0 \cdot 1$ riboflavin, 0.1]; trace element solution, $1 \mathrm{ml}$ [containing $\left(\mathrm{mg} \mathrm{l}^{-1}\right)$ : $\mathrm{H}_{3} \mathrm{BO}_{4}, 0.5 ; \mathrm{CuSO}_{4} .5 \mathrm{H}_{2} \mathrm{O}, 0.04 ; \mathrm{KI}, 0.1 ; \mathrm{FeCl}_{3} .6 \mathrm{H}_{2} \mathrm{O}, 0.2 ;$ $\left.\mathrm{MnSO}_{4} \cdot \mathrm{H}_{2} \mathrm{O}, 0 \cdot 2 ; \mathrm{Na}_{2} \mathrm{MoO}_{4} \cdot 2 \mathrm{H}_{2} \mathrm{O}, 0 \cdot 2 ; \mathrm{ZnSO}_{4} \cdot 7 \mathrm{H}_{2} \mathrm{O}, 0 \cdot 4\right]$. After adding the different carbon sources, at a final concentration of $0.2 \%$ $(w / v)$, the media were sterilized by filtration.

(ii) Qualitative enzyme tests with chromogenic substrates. These tests were performed in filter-sterilized medium ( $\mathrm{pH} 7.2)$ containing $0.05 \mathrm{M}$ Tris $/ \mathrm{HCl}$ buffer and $0.05 \%(\mathrm{w} / \mathrm{v})$ each of yeast extract (Oxoid) and biolactysate (bio-Merieux). Filter-sterilized solutions of the glycosidase substrates ( $p$-nitrophenyl-linked substrates) were added at final concentrations of $2 \mathrm{~mm}$. For L-valine-p-nitroanilide a concentration of $1 \mathrm{~mm}$ was used.

Testing procedure. To obtain homogeneous suspensions for inoculation of the different test wells, all strains were cultivated in liquid GYM medium for $72 \mathrm{~h}$ at $28^{\circ} \mathrm{C}$. After growth, the cell agglomerates were mechanically homogenized using a sterile Ultraturrax (Jahnke \&
Kunkel, Staufen, FRG) for $1 \mathrm{~min}$ at 4000 r.p.m. From this homogenate, $100 \mu \mathrm{l}$ aliquots were transferred to $5 \mathrm{ml}$ of $0.9 \%(\mathrm{w} / \mathrm{v})$ $\mathrm{NaCl}$ and each test well was filled with $50 \mu \mathrm{l}$ of the bacterial suspension. Test plates were covered with plastic seals (Flow Laboratories) and incubated at $28^{\circ} \mathrm{C}$ for $14 \mathrm{~d}$. Test results were read photometrically with a Multiscan MCC 340 photometer (Flow Laboratories). A carbon substrate utilization test was considered positive if $A_{414}$ (test) $-A_{414}$ (assimilation control) $>0.05$, and a qualitative enyzyme test was considered positive if $A_{414}$ (test) $-A_{414}$ (chromogenic substrate control) $>0 \cdot 3$. Because of the different growth characteristics of the strains, all test results were also checked visually.

Theoretical evaluation of the matrix. The matrix was further evaluated using the OVERMAT program (Sneath, $1980 \mathrm{c}$ ), which calculates the probability of significant overlap between the phena. For each pair of groups, a disjunction index $(W)$ and a corresponding nominal overlap $\left(V_{\mathrm{G}}\right)$ is calculated ranging from 1 for complete overlap to 0 for complete disjunction. The identification scores were calculated using the MATIDEN program (Sneath, 1979a), which provides several identification scores for known and unknown strains of $q$ taxa and $m$ characters. Percentages in the matrix, with 0 changed to 1 and 100 changed to 99 , are converted to proportions $P_{i J}$ for the $i$ th character of taxon $J$. The character states of an unknown $(u)$ are input and compared with each taxon in turn. Three identification coefficients were calculated.

1. Willcox probability $(p)$. This is the likelihood of $u$ against taxon $J$ divided by the sum of the likelihoods of $u$ against all $q$ taxa $\left(L_{u J}\right)$. The nearer the score approaches to $1 \cdot 0$, the better is the fit of an unknown with a taxon in the matrix.

2. Taxonomic distance $(d)$, which is given by $\sqrt{ }\left[\sum\left(u_{\mathrm{i}}-P_{\mathrm{i} J}\right)^{2} / m\right]$. This expresses the distance of an unknown from the centroid of the group with which it is compared.

3. The standard error of the taxonomic distance, which is given by the constant $(c)$ in the equation $d=\bar{d}_{J}+c s_{i J}$, where $\vec{d}_{J}$ is the mean distance of OTUs of taxon $J$ from the centroid and $s_{i j}$ is the standard deviation of those distances. An acceptable score is less than 2.0 to 3.0 , and about the half of the members of a taxon will have negative scores, indicating a stronger relationship to the centroid as the average.

More details of these scores are given by Sneath $(1979 a)$ and Williams et al. (1983b).

The results of the Willcox probability $p$ were grouped into different intervals $(p>0.99 ; 0.99>p \geq 0.90 ; 0.9>p \geq 0.8 ; 0.8>p \geq 0.5 ; p<$ $0 \cdot 5$ ), and the highest and lowest values of the taxonomic distance and the standard error were calculated for each phenon.

The MOSTTYP program (Sneath, 1980b) calculates the identification coefficients for the hypothetical median organism of each taxon in the matrix.

Practical evaluation of the matrix. The matrix was practically evaluated with 32 strains, all of them classified using the numerical survey of Williams et al. $(1983 a)$. The test data were again assessed using the MATIDEN program.

Computing. All calculations were done on a personal computer (Compaq Deskpro 80386).

\section{Results}

\section{Composition of the matrix}

The matrix (Table 1) consisted of 52 phena versus 50 tests, and included strains from both major and minor clusters obtained in the classification of Kämpfer $e t$ al. (1991). For single-member clusters a diagnostic table is 
given (Table 2). The 50 tests which were able to differentiate between the phena (Tables 1 and 2) included 45 carbon substrate utilization tests and five qualitative enzyme tests using chromogenic substrates. Most characters showed VSP indices $>30 \%$, and thus exceeded the value of $>25 \%$ recommended by Sneath $(1979 b)$. Scores ranged from $21 \cdot 26 \%$ (spermine utilization) to $67.01 \%$ ( $\alpha$-D-raffinose utilization). Sums of diagnostic scores produced by the DIACHAR program ranged from 11.75 ( $S$. rochei) to 25.27 ( $S$. fragilis). The OVERMAT program showed a total of 80 overlaps (from 1431 possible) taking a $5 \%$ level and a confidence interval of $P=90$. For the majority of major phena containing more than 10 strains, no overlap with other phena was observed. The theoretically best identification score for the most typical member of each phenon was calculated using the MOSTTYP program. Willcox probabilities for all phena containing two or more strains exceeded 0.999. Scores for taxonomic distances ranged from 0.184 ( $S$. albidoflavus) to 0.308 ( $S$. griseolus). Standard errors of the taxonomic distances were negative in most cases or achieved the score 0.05 for all phena containing only two strains.

A summary of scores obtained from the calculations of the programs CHARSEP, MOSTTYP, DIACHAR and OVERMAT is given in Table 3.

\section{Theoretical evaluation of the matrix}

All 782 isolates were tested against the matrix and the identification coefficients of the MATIDEN program were calculated. The organisms were grouped into different intervals of the Willcox probabilities $p$ obtained in these calculations (Table 4). A total of 591 strains $(75.57 \%)$ were identified with $p>0.99,69$ strains $(8.82 \%)$ were identified correctly with $p>0.9$, and 16 strains $(2.04 \%)$ with $p>0.8$. For 86 strains $(10.99 \%)$, the values for the Willcox probability ranged between 0.50 and 0.79 , i.e. the correct identification result was shown, but with low

Table 3. Summary of scores obtained in the construction and assessment of clusters containing two or more strains

\begin{tabular}{llr}
\hline \hline Program & \multicolumn{1}{c}{ Information } & Range of scores \\
\hline CHARSEP & VSP (\%) & 21.26 to 67.01 \\
MOSTTYP & Hypothetical median organism & \\
& $\quad$ Willcox probability & 0.999 to 1.000 \\
& Taxonomic distance $(d)$ & 0.184 to 0.308 \\
& $\quad$ Standard error of $d$ & -3.943 to 0.050 \\
DIACHAR & Sum of diagnostic scores & 11.75 to 25.27 \\
OVERMAT & Number of cluster pairs & \\
& with $>5 \%$ overlap & 80 \\
\hline \hline
\end{tabular}

Willcox probabilities. Twenty strains $(2.55 \%)$ were not correctly identified. The identification rate of the matrix (Willcox probability $>0.90$ ) was $84.39 \%$.

\section{Practical evaluation of the matrix}

As with the theoretical evaluation, the Willcox probabilities obtained from 32 strains were assigned to different intervals. All of the isolates were grouped into the correct phenon, although some with low Willcox probabilities. Twenty isolates $(62.50 \%)$ were identified with $p>0.99$, five $(15.62 \%)$ with $0.99>p \geq 0.90$, three $(9.37 \%)$ with $0.90>p \geq 0.80$, and four $(12.50 \%)$ with $p<0.80$. Strains of the phena $S$. albidoflavus, $S$. halstedii, $S$. griseus, S. fradiae, S. rimosus, S. albus and Streptoverticillium griseocarneum could be identified with Willcox probabilities $>0.999$. Taking a minimum Willcox probability of 0.90 for correct identification, a total of 25 strains $(78 \cdot 12 \%)$ were correctly identified.

\section{Discussion}

The use of numerical identification and the development of matrices for routine use has been successfully applied to various groups of bacteria. Large databases of physiological data are important sources of differentiating characters. The numerical studies of Williams et al. (1983a) and Kämpfer et al. (1991) showed that there is wide phenetic variation in the genus Streptomyces. Despite the agreement of both studies in the recovery of many major phena, there were differences in the composition and arrangement of several phena. Although the study of Kämpfer et al. (1991) included 821 strains which were tested for 329 characters, the results indicate, in comparison with the analysis of Williams et $a l$. (1983a), that the genus Streptomyces is still overspeciated, and the view that species of the genus Streptoverticillium should be included into the genus Streptomyces is supported.

As pointed out by Williams et al. (1983b), there is no simple, rapid procedure for objective identification of streptomycetes. Until now, there has been no alternative to the use of the probability matrices of Williams et al. (1983b) and Langham et al. (1989a) for correct identification. However, as no differentiating characters were given for the use of two probability matrices defined for major and minor clusters (Langham et al., 1989a), the use of two systems is still laborious. The use of a single matrix, with miniaturized tests, may be a more economical and less time-consuming alternative. However, although tests may be read photometrically, the results must also be checked visually, because of the different growth characteristics of the strains. 
Table 4. Theoretical evaluation of the probability matrix: numbers of strains assigned to the correct phenon with different Willcox probabilities (p)

\begin{tabular}{|c|c|c|c|c|c|c|c|}
\hline \multirow{2}{*}{ 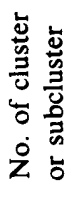 } & \multirow[b]{2}{*}{ Phenon } & \multirow{2}{*}{$\begin{array}{c}\text { Total } \\
\text { no. of } \\
\text { strains }\end{array}$} & \multicolumn{5}{|c|}{ Willcox probability $(p)$} \\
\hline & & & $\geq 0.99$ & $0.99>p \geq 0.9$ & $0.9>p \geq 0.8$ & $0.8>p \geq 0.5$ & $p<0.5$ \\
\hline $1-1$ & S. albidofiavus & (52) & 50 & 1 & 0 & 1 & 0 \\
\hline $1-2$ & S. halstedii & (6) & 5 & 1 & 0 & 0 & 0 \\
\hline $1-3$ & S. griseus & (81) & 66 & 4 & 1 & 8 & 2 \\
\hline $1-4$ & S. olivaceus & (6) & 6 & $\mathbf{0}$ & 0 & 0 & 0 \\
\hline $1-5$ & S. antibioticus & (19) & 13 & 4 & 0 & 2 & 0 \\
\hline $1-6$ & S. flaveolus & (16) & 10 & 1 & 1 & 3 & 1 \\
\hline $1-7$ & S. diastatochromogenes & (25) & 19 & 2 & 0 & 3 & 1 \\
\hline 2 & S. exfoliatus & (30) & 22 & 1 & 2 & 5 & 0 \\
\hline 3 & S. gelaticus & (3) & 3 & 0 & 0 & 0 & 0 \\
\hline 4 & S. graminofasciens & (6) & 6 & 0 & 0 & 0 & 0 \\
\hline 5 & S. parvus & (5) & 5 & 0 & 0 & 0 & 0 \\
\hline 6 & S. rochei & (79) & 40 & 13 & 2 & 20 & 4 \\
\hline 7 & S. prasinopilosus & $(7)$ & 7 & 0 & 0 & 0 & 0 \\
\hline 8 & Streptomyces sp. & (4) & 4 & 0 & 0 & 0 & 0 \\
\hline 9 & S. violaceus & $(118)$ & 60 & 24 & 5 & 23 & 6 \\
\hline 10 & S. sparsogenes & (2) & 2 & 0 & 0 & 0 & 0 \\
\hline 11 & S. psammoticus & (5) & 3 & 0 & 1 & 0 & 1 \\
\hline 12 & S. aurantiacus & (2) & 2 & 0 & 0 & 0 & 0 \\
\hline 13 & S. niveoruber & (9) & 7 & 2 & 0 & 0 & 0 \\
\hline 14 & Streptomyces sp. & (2) & 2 & 0 & 0 & 0 & 0 \\
\hline 17 & S. griseoloalbus & (2) & 2 & 0 & 0 & 0 & 0 \\
\hline 20 & S. chrysomallus & (6) & 5 & 0 & 0 & 0 & 1 \\
\hline 21 & S. thermovulgaris & (5) & 4 & 1 & 0 & 0 & 0 \\
\hline $22-1$ & $S v$. griseocarneum & $(51)$ & 49 & 1 & 1 & 0 & 0 \\
\hline $22-2$ & $S$. roseoviridis & (5) & 4 & 0 & 0 & 1 & 0 \\
\hline $22-3$ & S. lavendulae & (43) & 29 & 5 & 1 & 7 & 1 \\
\hline $22-4$ & S. misakiensis & (17) & 13 & 1 & 1 & 1 & 1 \\
\hline $22-5$ & S. fradiae & (17) & 12 & 1 & 0 & 3 & 1 \\
\hline 23 & S. griseolus & $(2)$ & 2 & 0 & 0 & 0 & 0 \\
\hline 24 & S. fungicidicus & (4) & 4 & 0 & 0 & 0 & 0 \\
\hline 25 & S. lydicus & (17) & 12 & 2 & 0 & 3 & 0 \\
\hline 26 & S. flavidovirens & (2) & 2 & 0 & 0 & 0 & 0 \\
\hline 27 & S. fradiae & (2) & 2 & 0 & 0 & 0 & 0 \\
\hline 28 & S. prasinus & (2) & 2 & 0 & 0 & 0 & 0 \\
\hline 30 & S. albus & (21) & 19 & 0 & 1 & 1 & 0 \\
\hline 33 & S. alboflavus & (19) & 15 & 1 & 0 & 3 & 0 \\
\hline 35 & S. rimosus & (26) & 21 & 3 & 0 & 1 & 1 \\
\hline 41 & S. endus & $(2)$ & 2 & 0 & 0 & 0 & 0 \\
\hline 44 & Streptomyces sp. & (2) & 2 & 0 & 0 & 0 & 0 \\
\hline 49 & $S$. roseiscleroticus & (2) & 2 & 0 & 0 & 0 & 0 \\
\hline 50 & S. violatus & (2) & 2 & 0 & 0 & 0 & 0 \\
\hline 51 & S. violaceusniger & (17) & 15 & 1 & 0 & 1 & 0 \\
\hline 64 & S. longissimus & (3) & 3 & 0 & 0 & 0 & 0 \\
\hline 65 & Streptomyces sp. & (2) & 2 & 0 & 0 & 0 & 0 \\
\hline 66 & S. flocculus & (3) & 3 & 0 & 0 & 0 & 0 \\
\hline 68 & S. sulphureus & (2) & 2 & 0 & 0 & 0 & 0 \\
\hline 69 & S. ochraceiscleroticus & (10) & 10 & 0 & 0 & 0 & 0 \\
\hline 76 & Streptomyces sp./Nocardia sp. & (9) & 9 & 0 & 0 & $\mathbf{0}$ & 0 \\
\hline 78 & S. fragilis & (2) & 2 & 0 & 0 & 0 & 0 \\
\hline 79 & S. lipmanii & (3) & 3 & 0 & 0 & 0 & 0 \\
\hline 80 & Streptomyces sp. & (3) & 3 & 0 & 0 & 0 & 0 \\
\hline 82 & Streptomyces sp. & (2) & 2 & 0 & 0 & 0 & 0 \\
\hline \multicolumn{2}{|c|}{ No. of strains: } & $(782)$ & 591 & 69 & 16 & 86 & 20 \\
\hline \multicolumn{2}{|c|}{ Percentages } & 100 & $75 \cdot 57$ & $8 \cdot 82$ & $2 \cdot 04$ & $10 \cdot 99$ & $2 \cdot 55$ \\
\hline
\end{tabular}


Our matrix was based on the classification of Kämpfer et al. (1991), which encompassed many more strains than that of Williams et al. (1983a), including those assigned to species category IV of Williams et al. (1989). The identification rate of $78.12 \%$ for 32 strains taking a Willcox probability of 0.90 as the level for correct identification was satisfactory compared with the value of $77 \%$ obtained by Langham et al. $(1989 a)$, who took a Willcox probability level of 0.85 for correct identification. This value is also in line with those obtained in other probabilistic systems, such as $70.8 \%$ for Gramnegative non-fermentative bacteria (Lapage et al., 1973), $50.5 \%$ for some 'coryneform' bacteria (Hill et al., 1978), $79.4 \%$ for vibrios (Dawson \& Sneath, 1985 ), $89.2 \%$ for Gram-negative fermentative bacteria (Holmes et al., 1986) and 70\% for bacilli (Priest \& Alexander, 1988).

As pointed out by Sneath $(1979 b)$, the Willcox probability is a Bayesian coefficient and the score is expressed as a proportion of the sum of the antilogarithms for all groups. It can occasionally happen than the unknown does not belong to any group of the matrix, but fits to one group better than the other alternatives, because the normalizing step $L_{u J} / \sum^{\mathrm{q}} L_{u J}$ gives the first alternative a score closer to 1.0 (Sneath, 1979a). The poor fit is indicated by numerous 'character against' scores, which have to be checked, as indicated by Langham et al. $(1989 b)$. On the other hand, the use of the taxonomic distance and the standard error of the taxonomic distance is not deceptive, if the true group to which the unknown belongs is not in the matrix, because the scores will be large. The criteria for a successful identification are thus a Willcox probability greater than 0.90 with low scores for taxonomic distance and its standard error; and 'characters against' scores should be zero or few (Williams et al., 1983b).

The problems of streptomycete identification shown by the low Willcox probabilities for several strains (Table 4) are largely a reflexion of the difficulties in streptomycete taxonomy. We did not include morphological or pigmentation characteristics, because it is generally accepted that more than one category of spore chains can be observed in the same species and the distinction between Retinaculiaperti and Spirales is not clear (Williams \& Wellington, 1980; Williams et al., 1989). The determination of the colour of the spore mass is also not easy (Kutzner, 1981), and especially with respect to spore colour and other morphological criteria, our study supports the view of Williams et al. (1983a) that these traditional characters, which are often difficult to determine (Williams \& Wellington, 1980; Kutzner, 1981), are inadequate for classification and identification. The most diagnostic physiological criteria were selected as objectively as possible.

Carbon substrate utilization tests have been found in earlier studies to be characters with great differentiation potential. The utilization of sucrose, L-arabinose, $i$ inositol, mannitol, rhamnose and raffinose were recommended as an aid to species differentiation in the International Streptomyces Project (Shirling \& Gottlieb, $1966 ; 1968 a, b ; 1969,1972)$ and these tests have been used in several identification schemes (Szabo et al., 1975; Küster, 1972; Nonamura, 1974; Pridham \& Tresner, 1974), including automated identification systems (Gyllenberg et al., 1975). These tests were also used in the probability matrices of Langham et al. (1989a), who found that the utilization of melibiose was an additional differentiating character. The utilization of organic acids such as malonate for identification purposes was recommended by Nitsch \& Kutzner (1969).

The use of qualitative enzyme tests for differentiation of streptomycetes was proposed by Goodfellow et al. (1987), who used growth-independent tests of the hydrolysis of methylumbelliferyl-linked substrates to differentiate between selected strains from the species and species-groups defined by Williams et al. $(1983 a)$.

Recently, quantitative chemotaxonomic methods have been applied to some species of the genus Streptomyces (O'Donnell, 1988), but the differentiation potential of quantitative fatty acid data at the species level is still questionable (Saddler et al., 1987).

It must be emphasized that streptomycete taxonomy is still developing. The phenetic diversity of streptomycetes is a major problem, and is the main reason for the large number of tests needed for species identification. Despite these problems, there is no alternative to a computer-assisted, numerical identification procedure for an objective assignment of an unknown streptomycete strain to a polythetically defined species. Based on the thesis that good classification is a prerequisite for accurate identification (Hill, 1974; Goodfellow, 1986), it is still necessary to use genetical methods on a large number of strains to confirm the taxonomic position of the numerically defined species.

\section{References}

Dawson, C. W. \& Sneath, P. H. A. (1985). A probability matrix for identification of vibrios. Journal of Applied Bacteriology 58, 407-423.

GoODFELlow, M. (1986). Actinomycetes systematics: present state and future prospects. In Biological, Biochemical and Biomedical Aspects of Actinomycetes, Part B, pp. 487-496. Edited by G. Szabo, S. Biro \& M. Goodfellow. Budapest: Academiai Kiado.

Goodfellow, M., Lonsdale, C., James, A. L. \& McNamara, O. C. (1987). Rapid biochemical tests for the characterisation of streptomycetes. FEMS Microbiology Letters 43, 39-44.

GyllenberG, H. G., Niemelä, T. K. \& NiEMi, S. J. (1975). A model for automated identification of streptomycetes. Postepy Higieny $i$ Medycyny Doswiadczalnej 29, 357-383.

Hill, L. R. (1974). Theoretical aspects of numerical identification. International Journal of Systematic Bacteriology 24, 494-499. 
Hill, L. R., Lapage, S. P. \& Bowie, I. S. (1978). Computer assisted identification of coryneform bacteria. In Coryneform Bacteria, pp. 181-215. Edited by I. J. Bousfield \& A. G. Callely. London: Academic Press.

Holmes, B., Pinning, C. A. \& Dawson, C. A. (1986). A probability matrix for the identification of Gram-negative, aerobic, nonfermentative bacteria that grow on nutrient agar. Journal of General Microbiology 132, 1827-1842.

KÄMPFER, P., KROPPENSTEDT, R. M. \& DOTT, W. (1991). A numerical classification of the genera Streptomyces and Streptoverticillium using miniaturized physiological tests. Journal of General Microbiology 137, 1831-1891.

KÜSTER, E. (1972). Simple working key for the classification and identification of named taxa included in the International Streptomyces Project. International Journal of Systematic Bacteriology 22, 139-148.

Kurylowicz, W., Paszkiewicz, A., WozNicka, W., KURzatKowsKi, W. \& SzUlGa, T. (1975). Classification of Streptomyces by different numerical methods. Postepy Higieny i Medycyny Doswiadczalnej 29, 281-355

KuTZNeR, H. J. (1981). Streptomyces. In The Prokaryotes : a Handbook of Habitats, Isolation and Identification of Bacteria, pp. 2028-2090. Edited by M. P. Starr, H. Stolp, H. G. Trüper, A. Balows \& H. G. Schlegel. Berlin: Springer Verlag.

Langham, C. D., Williams, S. T., Sneath, P. H. A. \& Mortimer, A. M. $(1989 a)$. New probability matrices for identification of Streptomyces. Journal of General Microbiology 135, 121-133.

Langham, C. D., Sneath, P. H. A., Williams, S. T. \& Mortimer, A. M. $(1989 b)$. Detecting aberrant strains in bacterial groups as an aid to constructing databases for computer identification. Journal of Applied Bacteriology 66, 339-352.

Lapage, S. P., Bascomb, B., Willcox, W. R. \& CuRtis, M. A. (1973). Identification of bacteria by computer: general aspects and perspectives. Journal of General Microbiology 77, 273-299.

LoCCI, R. \& Schofield, G. M. (1989). Genus Streptoverticillium Baldacci 1958, 15, emend. mut. char. Baldacci, Farina and Locci 1966, 168 AL. In Bergey's Manual of Systematic Bacteriology, pp. 24922504. Edited by S. T. Williams, M. Sharpe \& J. G. Holt. Baltimore: Williams \& Wilkins.

Loccl, R., Rogers, J., SARdi, G. \& Schofield, G. M. (1981). A preliminary numerical study on named species of the genus Streptoverticillium. Annali di Microbiologia 31, 115-121.

NITSCH, B. \& KUTZNER, H. J. (1969). Decomposition of oxalic acid and other organic acids by streptomycetes as a taxonomic aid. Zeitschrift für Allgemeine Mikrobiologie 9, 613-632.

NoNamURA, H. (1974). Key for classification and identification of 458 species of the streptomycetes included in ISP. Journal of Fermentation Technology 52, 78-92.

O'DonNell, A. (1988). Recognition of novel actinomycetes. In Actinomycetes in Biotechnology, pp. 69-88. Edited by M. Goodfellow, S. T. Williams \& M. Mordarski. London: Academic Press.

Pridham, T. G. \& Tresner, H. D. (1974). Streptomyces Waksman and Henrici 1943, 339. In Bergey's Manual of Determinative Bacteriology, 8th edn, pp. 748-829. Edited by R. E. Buchanan \& N. E. Gibbons. Baltimore: Williams \& Wilkins.

Priest, F. G. \& AleXander, B. (1988). A frequency matrix for probabilistic identification of some bacilli. Journal of General Microbiology 134, 3011-3018.

SAdDler, G. S., O'Donnell, A. G., Goodfellow, M. \& Minnikin, D. E. (1987). SIMCA pattern recognition in the analysis of streptomycete fatty acids. Journal of General Microbiology 133, 11371147.

ShirLing, E. B. \& GotTlieb, D. (1966). Methods for characterization of Streptomyces species. International Journal of Systematic Bacteriology 16, 313-340.
Shirling, E. B. \& GotTlieb, D. (1968a). Cooperative description of type cultures of Steptomyces. II. Species descriptions from first study. International Journal of Systematic Bacteriology 18, 69-118.

ShiRling, E. B. \& GotTlieb, D. $(1968 b)$. Cooperative description of type cultures of Streptomyces. III. Additional species descriptions from first and second studies. International Journal of Systematic Bacteriology 18, 279-391.

ShiRling, E. B. \& GotTlieb, D. (1969). Cooperative description of type cultures of Streptomyces. IV. Species descriptions from the second, third and fourth studies. International Journal of Systematic Bacteriology 19, 391-512.

ShIRLING, E. B. \& GotTliEB, D. (1972). Cooperative description of type cultures of Streptomyces. V. Additional descriptions. International Journal of Systematic Bacteriology 22, 265-394.

SNEATH, P. H. A. (1974). Test reproducibility in relation to identification. International Journal of Systematic Bacteriology 24, 508-523.

SNEATH, P. H. A. (1979a). BASIC program for identification of an unknown with presence-absence data against an identification matrix of percent positive characters. Computers and Geosciences 5 , 195-213.

SNEATH, P. H. A. (1979b). BASIC program for character separation indices from an identification matrix of percent positive characters. Computers and Geosciences 5, 349-357.

SNEATH, P. H. A. (1980a). BASIC program for the most diagnostic properties of groups from an identification matrix of percent positive characters. Computers and Geosciences 6, 21-26.

SNEATH, P. H. A. (1980 b). BaSIC program for determining the best identification scores possible for the most typical example when compared with an identification matrix of percent positive characters. Computers and Geosciences 6, 27-34.

SNEATH, P. H. A. $(1980 c)$. BASIC program for determining overlap between groups in an identification matrix of percent positive characters. Computers and Geosciences 6, 267-278.

Szabo, I. M., Marton, M., Buti, I. \& Fernandez, C. (1975). A diagnostic key for the identification of 'species' of Streptomyces and Streptoverticillium included in the International Streptomyces Project. Acta Botanica Academiae Scientiarum Hungaricae 21, 387-418.

Willcox, W. R., Lapage, S. P., Bascomb, S. \& Curtis, M. A. (1973). Identification of bacteria by computer: theory and programming. Journal of General Microbiology 77, 317-330.

Williams, S. T. \& Wellington, E. M. H. (1980). Micromorphology and fine structure of actinomycetes. In Microbiological Classification and Identification, pp. 139-165. Edited by M. Goodfellow \& R. G. Board. London: Academic Press.

Williams, S. T., Goodfellow, M., Alderson, G., Wellington, E. M. H., SNEATH, P. H. A. \& SACKIN, M. J. (1983a). Numerical classification of Streptomyces and related genera. Journal of General Microbiology 129, 1743-1813.

Williams, S. T., Goodfellow, M., Wellington, E. M. H., Vickers, J. C., Alderson, G., Sneath, P. H. A., Sackin, M. J. \& Mortimer, A. M. $(1983 b)$. A probability matrix for identification of some streptomycetes. Journal of General Microbiology 129, 1815-1830.

Williams, S. T., Locci, R., Vickers, J. C., SChofield, G. M., SNeath, P. H. A. \& Mortimer, A. M. (1985). Probabilistic identification of Streptoverticillium species. Journal of General Microbiology 131, 18811889.

Williams, S. T., Goodfellow, M. \& Alderson, G. (1989). Genus Streptomyces (Waksman \& Henrici 1943) 339AL. In Bergey's Manual of Systematic Bacteriology, vol. 4, pp. 2452-2492. Edited by S. T. Williams, M. E. Sharpe \& J. G. Holt. Baltimore: Williams \& Wilkins. 